\title{
Effect of Mn on Microstructure and Mechanical Properties of Al-4Ni Alloy
}

\author{
JIAO FANG ${ }^{1}$ XIXI DONG,${ }^{1}$ and SHOUXUN JI (i) ${ }^{1,2}$ \\ 1.-Brunel Centre for Advanced Solidification Technology (BCAST), Brunel University \\ London, Uxbridge UB8 3PH, Middlesex, UK. 2.—e-mail: shouxun.ji@brunel.ac.uk
}

The application of aluminum alloys at elevated temperatures has been attractive for decades, and Al-Ni-based alloys have recently been recognized as potential candidates. The effect of $\mathrm{Mn}$ on $\mathrm{Al}-4 \mathrm{Ni}$ alloy has been investigated in this work. Addition of $\mathrm{Mn}$ transformed the eutectics from $\mathrm{Al}_{3} \mathrm{Ni} / \alpha-\mathrm{Al}$ to $\mathrm{Al}_{9}(\mathrm{Ni}, \mathrm{Mn})_{2} / \alpha$-Al phases. $\mathrm{Mn}$ also improved the tensile strength at both $25^{\circ} \mathrm{C}$ and $250^{\circ} \mathrm{C}$. The yield strength at $25^{\circ} \mathrm{C}$ increased from $48 \mathrm{MPa}$ to $92 \mathrm{MPa}$ with $1.87 \% \mathrm{Mn}$ and then to $117 \mathrm{MPa}$ with $3.77 \% \mathrm{Mn}$. At $250^{\circ} \mathrm{C}$, the yield strength increased from $35 \mathrm{MPa}$ to $82 \mathrm{MPa}$ with $1.87 \% \mathrm{Mn}$ and then to $101 \mathrm{MPa}$ with $3.77 \% \mathrm{Mn}$. The alloys with $\mathrm{Mn}$ also showed less strength loss than Al-4Ni alloy at $250^{\circ} \mathrm{C}$. The eutectic $\mathrm{Al}_{9}(\mathrm{Ni}, \mathrm{Mn})_{2}$ phase showed good thermal stability. No coarsening was observed after $2000 \mathrm{~h}$ at $250^{\circ} \mathrm{C}$.

\section{INTRODUCTION}

The development of aluminum alloys for application at elevated temperatures has been attractive and an important topic for several decades. Cast AlSi-based alloys are very commonly used in engine manufacturing. However, Al-Si-based alloys with $\mathrm{Si}$ content varying from $6 \%$ to $12 \%$ are typically limited to use below $175^{\circ} \mathrm{C} .^{1}$ Above this temperature, their mechanical properties degrade rapidly as a result of dispersoid and precipitate coarsening ${ }^{2,3}$ In addition, the development of diesel and direct fuel injection gasoline engines with high specific powers has posed challenges to existing Al-Si alloys due to the requirement for increased working pressures and temperatures that call for aluminum alloys capable of working at higher temperatures.

Considerable efforts have been made from different aspects to improve the mechanical performance of aluminum alloys at elevated temperatures. One attempt aimed to modify $\mathrm{Al}-\mathrm{Si}$ alloys with heatresistant $\mathrm{Al}_{3} \mathrm{X}$ dispersoids and precipitates. Transition metals such as $\mathrm{Sc}, \mathrm{Zr}, \mathrm{Ti}, \mathrm{V}$, and $\mathrm{Ni}^{4-13}$ were found to be effective. However, the volume fraction of $\mathrm{Al}_{3} \mathrm{X}$ phase obtained through precipitation is usually very low, and some of these elements are

(Received June 10, 2021; accepted September 13, 2021; published online October 15, 2021) very expensive, thus limiting industrial applications of such materials. Other attempts aimed to develop new alloys such as Al-Fe-V-Si, Al-Fe-Mo-V, Al-FeGd, and Al-Ni-Y-Co. ${ }^{14-17}$ Some of these alloys require rapid solidification to improve their effectiveness, and it is difficult to achieve satisfactory results using conventional casting methods. Therefore, their high cost and technological difficulties in producing large-size and complex-shaped parts are unavoidable hurdles for industrial applications.

Attempts to use the Al-Ni-Mn system have been made over the past few years. ${ }^{18-20}$ The main reasons are that the $\mathrm{Al}-\mathrm{Ni}$ binary system has a higher eutectic temperature $\left(\sim 640^{\circ} \mathrm{C}\right)$ and the $\mathrm{Al}_{3} \mathrm{Ni}$ phase is stable up to $600^{\circ} \mathrm{C},{ }^{21,22}$ offering potential for application at elevated temperatures. The microstructures of Al-Ni-Mn alloys obtained at a cooling rate of $90 \mathrm{~K} / \mathrm{s}$ and $5 \mathrm{~K} / \mathrm{s}$ have been investigated. ${ }^{20}$ The eutectic structure was reported to be $\alpha-\mathrm{Al} / \mathrm{Al}_{3} \mathrm{Ni}$, and an $\mathrm{O}$ phase was observed. However, many open questions regarding the $\mathrm{Al}-$ $\mathrm{Ni}-\mathrm{Mn}$ system remain, in particular the effect of $\mathrm{Mn}$ on the microstructure and mechanical properties at room and elevated temperatures and the thermal stability of Al-Ni-Mn alloys.

Therefore, in the work presented herein, we aimed to study the effect of Mn on the microstructure and mechanical properties of $\mathrm{Al}-4 \mathrm{Ni}$ (all compositions hereafter in wt.\% unless otherwise specified) alloy processed by permanent mold 
casting. Because the eutectic point of binary $\mathrm{Al}-\mathrm{Ni}$ alloy contains $5.69 \% \mathrm{Ni}$, the hypoeutectic $\mathrm{Al}-4 \mathrm{Ni}$ alloy was expected to be able to provide good castability and sufficient eutectic phases to balance the manufacturing and mechanical properties. Three levels of Mn were introduced to investigate the formation of Mn-containing intermetallic phase and the effect on the mechanical performance. The microstructure and mechanical properties were examined at both $25^{\circ} \mathrm{C}$ and $250^{\circ} \mathrm{C}$. The discussion focuses on the microstructure, strengthening mechanism, and thermal stability of the Al-Ni-Mn alloys.

\section{EXPERIMENTAL PROCEDURES}

\section{Alloy Preparation and Casting}

Four experimental alloys (Al-4Ni, Al-4Ni-2Mn, $\mathrm{Al}-4 \mathrm{Ni}-3 \mathrm{Mn}$, and $\mathrm{Al}-4 \mathrm{Ni}-4 \mathrm{Mn}$ ) were prepared by melting $\mathrm{Al}-20 \mathrm{Ni}$ and $\mathrm{Al}-20 \mathrm{Mn}$ master alloys with pure aluminum (99.8\%) in an electric resistance furnace at $800^{\circ} \mathrm{C}$. The melt was held for at least $1 \mathrm{~h}$ before degassing with Ar using a rotary degasser at $300 \mathrm{rpm}$ for $5 \mathrm{~min}$. The melt temperature was then recovered to $750^{\circ} \mathrm{C}$, followed by casting into a steel mold designed according to ASTM B-108, resulting in two standard tensile bars with gauge length of 50 $\mathrm{mm}$ and diameter of $10 \mathrm{~mm}$. The compositions of the experimental alloys were determined by inductively coupled plasma optical emission spectrometry (ICPOES). The actual and nominal compositions are Al$4.04 \mathrm{Ni}$ (used as $\mathrm{Al}-4 \mathrm{Ni}$ ), $\mathrm{Al}-4.24 \mathrm{Ni}-1.87 \mathrm{Mn}$ (used as $\mathrm{Al}-4 \mathrm{Ni}-2 \mathrm{Mn}$ ), $\mathrm{Al}-4.0 \mathrm{Ni}-3.01 \mathrm{Mn}$ (used as Al-4Ni$3 \mathrm{Mn}$ ), and $\mathrm{Al}-3.82 \mathrm{Ni}-3.77 \mathrm{Mn}$ (used as Al-4Ni$4 \mathrm{Mn})$. Impurities were well controlled. The contents of $\mathrm{Fe}$ and $\mathrm{Si}$ were under 0.18 and 0.10 , respectively.

\section{Microstructure Analysis and Tensile Testing}

Samples for scanning electron microscopy (SEM) investigation were taken from the middle of tensile testing bars and prepared using standard metallographic techniques. To reveal the morphology of phases, deep etching was performed with 10 vol.\% $\mathrm{HCl}$ solution for $10 \mathrm{~min}$ to $20 \mathrm{~min}$. Microstructures were characterized using a ZEISS SUPRA ${ }^{\mathrm{TM}} 35 \mathrm{VP}$ SEM. Quantitative analysis was performed using a JEOL JXA-8230 electron probe microanalyzer (EPMA) coupled with wavelength-dispersive spectroscopy (WDS) detectors, operating at $15 \mathrm{kV}$. Samples for transmission electron microscopy (TEM) were prepared by using a Gatan Precision ion polishing system (PIPs). Foils were characterized by JEOL JEM-2100F at a working voltage of $200 \mathrm{kV}$.

Tensile testing was conducted using an Instron 5569 electromechanical system. For the test at ambient temperature $\left(25^{\circ} \mathrm{C}\right)$, the extension rate was set at $1 \mathrm{~mm} / \mathrm{min}$ using an extensometer with $50 \mathrm{~mm}$ gauge length (Instron Static Axial Clip-on Extensometer, 2630-113). For testing at $250^{\circ} \mathrm{C}$, the samples were placed in a ventilated environmental chamber that can be controlled at $\pm 2^{\circ} \mathrm{C}$. During testing, the samples were preheated to $250^{\circ} \mathrm{C}$ and maintained at this temperature for $40 \mathrm{~min}$ in the chamber before applying tension. Since the extensometer could not work at $250^{\circ} \mathrm{C}$, the elongation was obtained from accurately positioned lines on the gauge length of $50 \mathrm{~mm}$ and measured using a micrometer before and after the tensile test. A minimum of three measurements were taken for each sample, and the average was taken as the result. Hardness testing was conducted using a 432 SVD digital auto turret macro-Vickers hardness tester using a load of $10 \mathrm{~kg}$ and dwell time of $10 \mathrm{~s}$. A minimum of eight measurements were taken for each sample, and the average was taken as the result.

\section{RESULTS AND DISCUSSION}

\section{Microstructure}

The typical microstructures of the $\mathrm{Al}-4 \mathrm{Ni}$ and $\mathrm{Al}-$ 4Ni-2Mn alloys are shown in Fig. 1. These two alloys displayed similar microstructure comprising primary $\alpha$-Al dendrites and eutectic phases. In the $\mathrm{Al}-4 \mathrm{Ni}$ alloy, the primary $\alpha-\mathrm{Al}$ contained $0.28 \% \mathrm{Ni}$, while in the $\mathrm{Al}-4 \mathrm{Ni}-2 \mathrm{Mn}$ alloy, the $\alpha$-Al contained about $0.43 \% \mathrm{Ni}$ and $1.6 \% \mathrm{Mn}$. Ni shows very limited solubility in $\mathrm{Al},{ }^{21}$ while $\mathrm{Mn}$ has a maximum solubility of $1.8 \%$ in $\mathrm{Al}^{23}$ Hence, the concentration of $\mathrm{Mn}$ in $\alpha-\mathrm{Al}$ is much higher than that of $\mathrm{Ni}$. The eutectic intermetallic phase in both the $\mathrm{Al}-4 \mathrm{Ni}$ and Al-4Ni-2Mn alloys showed rod-like shape. The eutectic intermetallic phase in the $\mathrm{Al}-4 \mathrm{Ni}$ alloy showed a composition of $\mathrm{Al}-23.4$ at. $\% \mathrm{Ni}$, which is a typical $\mathrm{Al}_{3} \mathrm{Ni}$ phase according to the equilibrium phase diagram of $\mathrm{Al}-\mathrm{Ni}$ binary alloys. ${ }^{21}$ The eutectic intermetallic phase in the Al-4Ni-2Mn alloy, however, showed the composition $\mathrm{Al}-13.5$ at.\% $\mathrm{Ni}-3.7$ at.\% Mn. Clearly, this is not $\mathrm{Al}_{3} \mathrm{Ni}$ but closer to the $\mathrm{Al}_{9}(\mathrm{Ni}, \mathrm{Mn})_{2}$ phase, which is reported to have the monoclinic lattice structure of $\mathrm{Al}_{9} \mathrm{Co}_{2}$ phase with lattice parameters of $a=0.8585 \mathrm{~nm}, b=0.6269 \mathrm{~nm}$, $c=0.6205 \mathrm{~nm}$, and $\beta=95.34^{\circ} .^{24}$ TEM micrographs and diffraction patterns of the intermetallic phase are presented in Fig. 1c, d, and e. The electron diffraction patterns were indexed to $\mathrm{Al}_{9}(\mathrm{Ni}, \mathrm{Mn})_{2}$ phase along zone axis [001] and [101]. Therefore, the eutectic intermetallic phase in the $\mathrm{Al}-4 \mathrm{Ni}-2 \mathrm{Mn}$ alloy was confirmed to be $\mathrm{Al}_{9}(\mathrm{Ni}, \mathrm{Mn})_{2}$ phase. Addition of $\mathrm{Mn}$ to $\mathrm{Al}-4 \mathrm{Ni}$ alloy resulted in a transformation of the eutectic structure from $\mathrm{Al}_{3} \mathrm{Ni} / \alpha-\mathrm{Al}$ to $\mathrm{Al}_{9}(\mathrm{Ni}, \mathrm{Mn})_{2} / \alpha-\mathrm{Al}$. This is different from the eutectic intermetallic phase identified by previous studies, ${ }^{18,22}$ in which the eutectic $\mathrm{Al}_{3} \mathrm{Ni}$ phase was reported in $\mathrm{Al}-\mathrm{Ni}-\mathrm{Mn}$ alloys. $\mathrm{Al}_{9}(\mathrm{Ni}, \mathrm{Mn})_{2}$ phase was also observed in the works of Balanetskyy ${ }^{24}$ and $\mathrm{Yu}^{25} \mathrm{Al}_{9}(\mathrm{Ni}, \mathrm{Mn})_{2}$ phase has a $\mathrm{Al}_{9} \mathrm{Co}_{2}$-type lattice structure, which is similar to $\mathrm{Al}_{9}(\mathrm{Fe}, \mathrm{Ni})_{2}$ (also known as $\mathrm{Al}_{9} \mathrm{FeNi}$ phase) ${ }^{26}$ For the $\mathrm{Al}_{9}(\mathrm{Fe}$, $\mathrm{Ni})_{2}$ phase, both $\mathrm{Ni}$ and $\mathrm{Fe}$ possibly appear at sites that originally corresponded to $\mathrm{Co}$ in $\mathrm{Al}_{9} \mathrm{Co}_{2}$ phase. 
This is most likely also the case for the $\mathrm{Al}_{9}(\mathrm{Ni}, \mathrm{Mn})_{2}$ phase. Both $\mathrm{Ni}$ and $\mathrm{Mn}$ can occupy each Co site, , thus the concentration of $\mathrm{Ni}$ and $\mathrm{Mn}$ may not be fixed. Balanetskyy ${ }^{24}$ reported a composition of $\mathrm{Al}$ 14.7 at. $\% \mathrm{Ni}-2.8$ at. $\% \mathrm{Mn}$, while $\mathrm{Yu}^{25}$ reported a composition of Al-16.5 at.\%Ni-3.2 at.\% $\mathrm{Mn}$ for the $\mathrm{Al}_{9}(\mathrm{Ni}, \mathrm{Mn})_{2}$ phase. In this paper, the composition for $\mathrm{Al}_{9}(\mathrm{Ni}, \mathrm{Mn})_{2}$ phase was measured as $\mathrm{Al}-13.5$ at. $\% \mathrm{Ni}-3.7$ at. $\% \mathrm{Mn}$. Although the concentration of $\mathrm{Ni}$ and $\mathrm{Mn}$ may vary, the total amount of $\mathrm{Ni}$ and $\mathrm{Mn}$ remains at a level of 18 at.\%. It is thus clear that addition of $\mathrm{Mn}$ to $\mathrm{Al}-4 \mathrm{Ni}$ alloy resulted in a transformation of the eutectic structure from $\mathrm{Al}_{3} \mathrm{Ni} / \alpha-\mathrm{Al}$ to $\mathrm{Al}_{9}(\mathrm{Ni}, \mathrm{Mn})_{2} / \alpha-\mathrm{Al}$.

Figure 2 shows the difference between the intermetallic phases in the $\mathrm{Al}-4 \mathrm{Ni}$ alloys with different $\mathrm{Mn}$ contents. In the Al-4Ni-3Mn alloy, two different primary intermetallic phases were observed. One was coarse gray particles showing hexagonal shapes with black cores inside (Fig. 2a). The core inside showed a composition of $\mathrm{Al}-1.35 \mathrm{Mn}-0.37 \mathrm{Ni}$, which is $\alpha$-Al. EPMA revealed the average composition of the hexagonal phase to be $\mathrm{Al}-15.6$ at. $\% \mathrm{Mn}-4.8$ at. $\% \mathrm{Ni}$, corresponding to the formula $\mathrm{Al}_{16.6} \mathrm{Mn}_{3} \mathrm{Ni}_{1}$. This hexagonal phase was identified as k-phase, which has a composition of Al-(14.7-18.9) at.\%Mn-(1.3$5.9)$ at. $\% \mathrm{Ni}^{24}$ The k-phase was reported to have the hexagonal lattice structure of $\mathrm{Al}_{14.1} \mathrm{Cr}_{3.4} \mathrm{Ni}_{1.1}$ phase existing in Al-Cr-Ni and Al-Ni-Mn alloys. ${ }^{27}$ Another, acicular morphology is shown in Fig. $2 b$ for the intermetallic phase. The composition was measured to be $\mathrm{Al}-12.6$ at.\% $\mathrm{Mn}-7.0$ at.\% $\mathrm{Ni}$, which is close to the formula $\mathrm{Al}_{60} \mathrm{Mn}_{11} \mathrm{Ni}_{4}$. There are two lattice structures for the formula $\mathrm{Al}_{60} \mathrm{Mn}_{11} \mathrm{Ni}_{4}$, viz. $\mathrm{Al}_{60} \mathrm{Mn}_{11} \mathrm{Ni}_{4}$ and $\mathrm{C}_{3, \mathrm{I}}-\mathrm{Al}_{60} \mathrm{Mn}_{11} \mathrm{Ni}_{4} . \quad \mathrm{Al}_{60} \mathrm{Mn}_{11} \mathrm{Ni}_{4}$ phase has orthorhombic structure with lattice parameters of $a=0.755 \mathrm{~nm}, b=1.250 \mathrm{~nm}$, and $c=$ $2.380 \mathrm{~nm}$, while $\mathrm{C}_{3, \mathrm{I}}-\mathrm{Al}_{60} \mathrm{Mn}_{11} \mathrm{Ni}_{4}$ also has orthorhombic structure but with lattice parameters of $a=3.27 \mathrm{~nm}, b=1.25 \mathrm{~nm}$, and $c=2.38 \mathrm{~nm}$. Obviously, both $\mathrm{C}_{3, \mathrm{I}}-\mathrm{Al}_{60} \mathrm{Mn}_{11} \mathrm{Ni}_{4}$ and $\mathrm{Al}_{60} \mathrm{Mn}_{11} \mathrm{Ni}_{4}$ are orthorhombic structures and the only difference lies in the value of the lattice parameter $a$. Hence, it is not easy to distinguish $\mathrm{C}_{3 \mathrm{I}}-\mathrm{Al}_{60} \mathrm{Mn}_{11} \mathrm{Ni}_{4}$ from $\mathrm{Al}_{60} \mathrm{Mn}_{11} \mathrm{Ni}_{4}$ without detailed TEM diffraction patterns. $\mathrm{Al}_{60} \mathrm{Mn}_{11} \mathrm{Ni}_{4}$ was referred to as X-phase or $\mathrm{R}$ phase in Refs. 28 and 29 but as O-phase in Ref. 20 Even earlier, Balanetskyy ${ }^{24}$ referred to the $\mathrm{C}_{3, \mathrm{I}^{-}}$ $\mathrm{Al}_{60} \mathrm{Mn}_{11} \mathrm{Ni}_{4}$ as O-phase, not $\mathrm{Al}_{60} \mathrm{Mn}_{11} \mathrm{Ni}_{4}$. Because of this remaining uncertainty and as these two
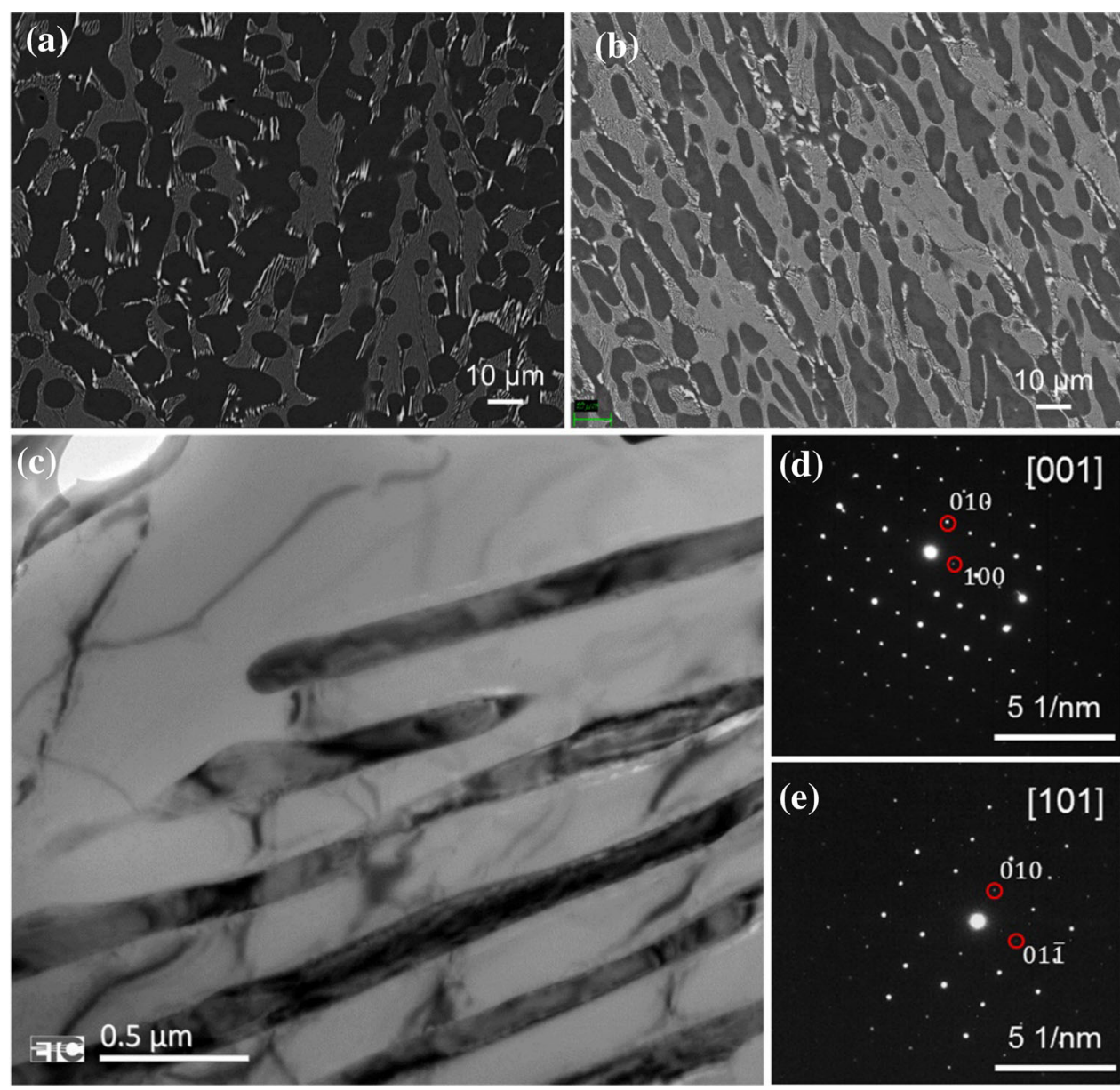

Fig. 1. SEM micrographs showing typical microstructure of (a) Al-4Ni alloy and (b) Al-4Ni-2Mn alloy. (c) TEM micrograph showing eutectic $\mathrm{Al}_{9}(\mathrm{Ni}, \mathrm{Mn})_{2}$ phase. Electron diffraction patterns along (d) [001] and (e) [101] zone axis. 
phases are difficult to distinguish, we use O-phase for $\mathrm{Al}_{60} \mathrm{Mn}_{11} \mathrm{Ni}_{4}$ phase in the present study.

The typical microstructures of $\mathrm{Al}-4 \mathrm{Ni}-4 \mathrm{Mn}$ alloy are presented in Fig. 2c, d. With increasing Mn level, the amount of intermetallic phase increased. Dendritic intermetallic is observed in Fig. 2c, and EDS analysis confirmed that it was k-phase. The size of k-phase increased, and the morphology also changed, when the $\mathrm{Mn}$ content in the Al-Ni alloys was increased. It changed from hexagonal shape with $\alpha$-Al core inside to become massive dendritic shapes. Moreover, coarse $\mathrm{Al}_{6} \mathrm{Mn}$ phase was also observed at a level of several hundred micrometers in the Al-4Ni-4Mn alloy, which displayed a welldeveloped dendritic morphology. With addition of $1.87 \% \mathrm{Mn}$, the eutectic structure transformed from $\alpha-\mathrm{Al} / \mathrm{Al}_{3} \mathrm{Ni}$ to $\alpha-\mathrm{Al} / \mathrm{Al}_{9}(\mathrm{Ni}, \mathrm{Mn})_{2}$. When the $\mathrm{Mn}$ level was increased to 3.01, k-phase and O-phase were formed, and when the Mn level was increased further to $3.77 \%, \mathrm{Al}_{6} \mathrm{Mn}$ dendrites were observed.

\section{Mechanical Performance at $25^{\circ} \mathrm{C}$ and $250^{\circ} \mathrm{C}$}

The hardness of the Al-Ni-Mn alloys with different $\mathrm{Mn}$ levels is shown in Fig. 3a. Clearly, the hardness increased linearly with increasing $\mathrm{Mn}$ level. The $\mathrm{Al}-4 \mathrm{Ni}$ alloy presented hardness of 42.3 $\mathrm{HV}_{10}$ while the $\mathrm{Al}-4 \mathrm{Ni}-2 \mathrm{Mn}$ alloy showed a $53 \%$ increase to $64.5 \mathrm{HV}_{10}$. When the $\mathrm{Mn}$ level was further increased to $3.01 \%$ and $3.77 \%$, the hardness increased to $67.2 \mathrm{HV}_{10}$ and $69.9 \mathrm{HV}_{10}$, respectively.

Figure $3 \mathrm{~b}$ presents the tensile strength of the Al$4 \mathrm{Ni}-\mathrm{Mn}$ alloys at ambient temperature $\left(25^{\circ} \mathrm{C}\right)$. It is seen that the yield strength exhibited a significant increase with increasing $\mathrm{Mn}$ content. The yield strength was $48 \mathrm{MPa}$ for the $\mathrm{Al}-4 \mathrm{Ni}$ alloy but 92 $\mathrm{MPa}$ for the Al-4Ni-2Mn alloy. When the $\mathrm{Mn}$ content was increased to $3.01 \%$ and $3.77 \%$, the yield strength increased monotonically to $110 \mathrm{MPa}$ and $117 \mathrm{MPa}$, respectively.

Strengthening of alloys can basically be classified into five mechanisms: solid-solution strengthening, second-phase strengthening, grain-boundary strengthening, precipitate strengthening, and strain hardening. The maximum solubility of $\mathrm{Ni}$ in $\alpha-\mathrm{Al}$ is $0.05 \%$ at $640^{\circ} \mathrm{C}$, which is negligible for solidsolution strengthening, while $\mathrm{Mn}$ has a maximum solubility of $1.8 \%$ in $\alpha$-Al at $658^{\circ} \mathrm{C} .^{23}$ The $\alpha$-Al phase in experimental $\mathrm{Al}-4 \mathrm{Ni}-2 \mathrm{Mn}$ alloy contained $1.6 \%$ $\mathrm{Mn}$. As the atomic radius of $\mathrm{Mn}$ is $1.40 \AA$ while that of $\mathrm{Al}$ is $1.25 \AA$, the solid solution with $\mathrm{Mn}$ in $\mathrm{Al}$ results in lattice distortion, which hinders dislocation motion under loading. Therefore, addition of $\mathrm{Mn}$ introduces solid-solution strengthening in Al$\mathrm{Ni}-\mathrm{Mn}$ alloys.

On the other hand, increasing the level of $\mathrm{Mn}$ addition increased the amount of eutectic phases and primary intermetallic phases. The measured volume fractions of different phases in the experimental Al-4Ni-Mn alloys are presented in Table I. As seen, the Al-4Ni alloy contained 44 vol.\% of eutectic phases. With $1.87 \% \mathrm{Mn}$ addition, the eutectic phases increased to 51 vol.\%, while no primary intermetallic phase was found. With $3.01 \%$ $\mathrm{Mn}$ addition, the eutectic phases increased to 58 vol.\%, and the primary intermetallic phase was
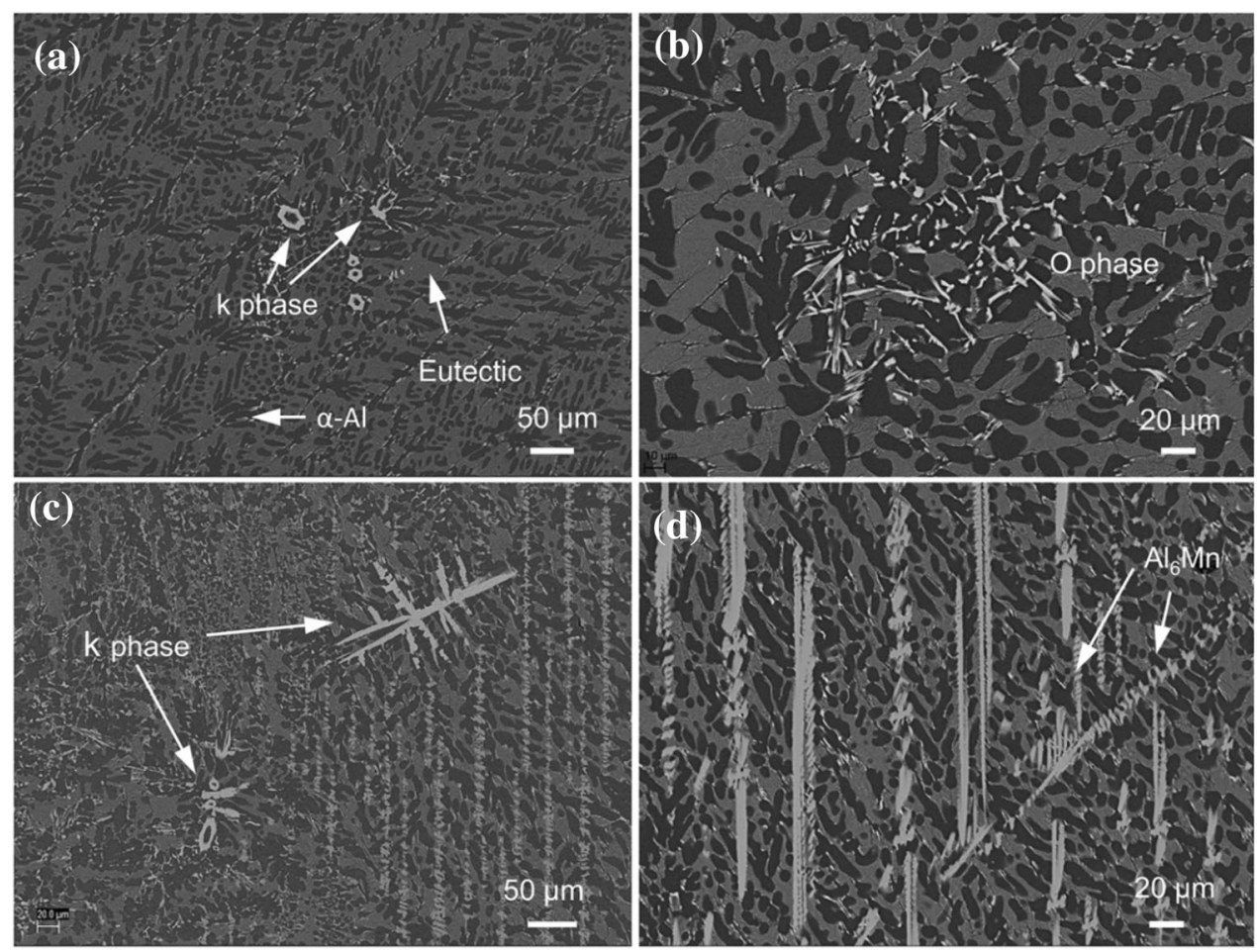

Fig. 2. Typical microstructure of intermetallic in (a, b) Al-4Ni-3Mn alloy and (c, d) Al-4Ni-4Mn alloy. 
found at a level of 1 vol.\%. When the Mn content was increased to $3.77 \%$, the eutectic phases increased to $60 \mathrm{vol} . \%$ and the primary intermetallic phase increased to $5 \mathrm{vol} . \%$. This increase in the eutectic phases and primary intermetallic phases can introduce second-phase strengthening. This can therefore explain the observed improvement in the yield strength on Mn addition.

The ultimate tensile strength also displayed significant improvement with increasing Mn content at ambient temperature. It increased dramatically from $129 \mathrm{MPa}$ for the $\mathrm{Al}-4 \mathrm{Ni}$ alloy to $204 \mathrm{MPa}$ for the Al-4Ni-2Mn alloy, then reached a peak strength of $227 \mathrm{MPa}$ for $3.01 \% \mathrm{Mn}$. However, when the Mn content was increased further to $3.77 \%$, the ultimate tensile strength did not increase but rather decreased slightly to $225 \mathrm{MPa}$. As presented in Fig. 2d, the dendritic $\mathrm{Al}_{6} \mathrm{Mn}$ phase appeared in the $\mathrm{Al}-4 \mathrm{Ni}-4 \mathrm{Mn}$ alloy, having a size of several hundred micrometers. For this type of tough and large-size intermetallic phase, the localized stress on the

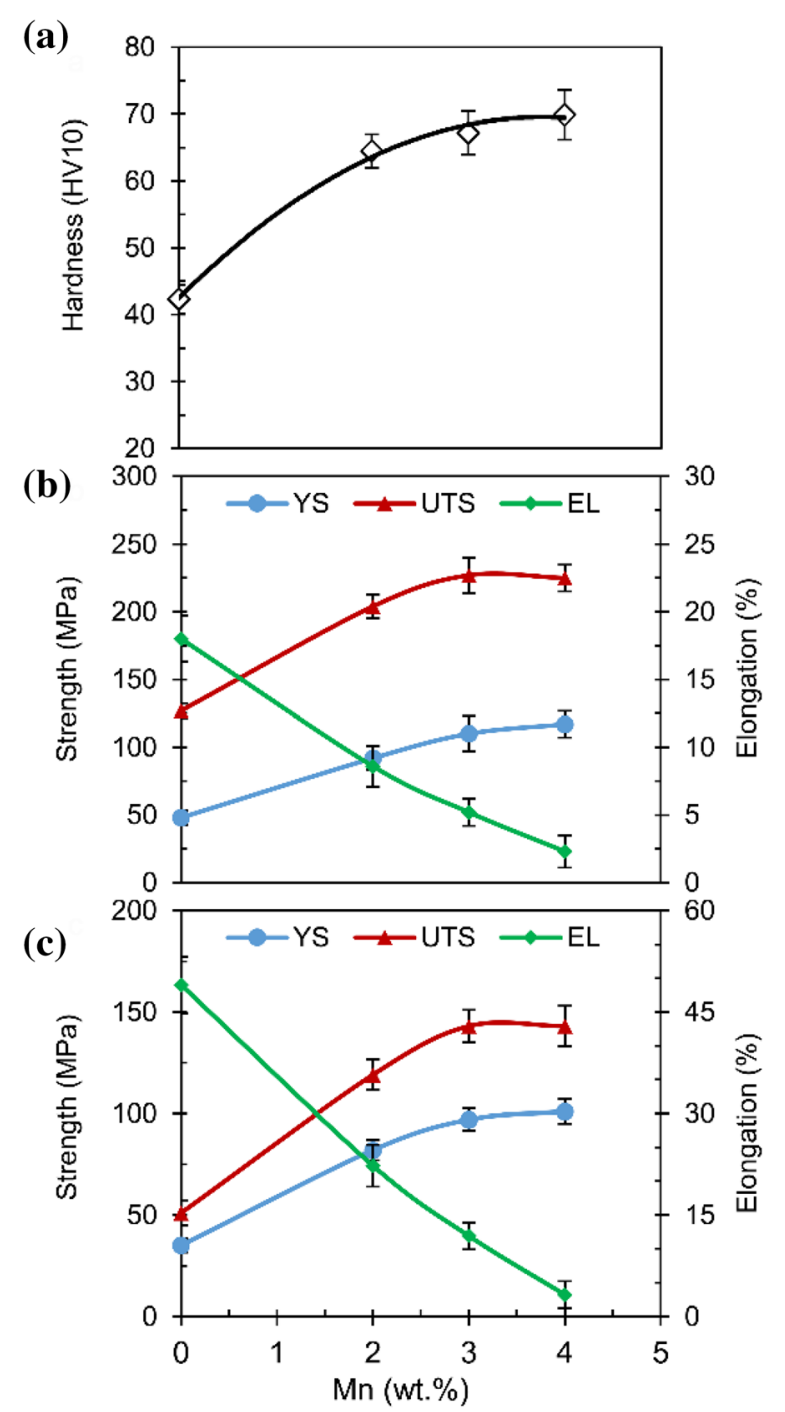

Fig. 3. (a) Effect of Mn content on hardness, and tensile property at (b) $25^{\circ} \mathrm{C}$ and (c) $250^{\circ} \mathrm{C}$. particle surface and especially in the dendrite corners and tips increases quickly and accelerates fracture of the material. Therefore, the Al- $4 \mathrm{Ni}-4 \mathrm{Mn}$ alloy presented lower ultimate tensile strength than the Al-4Ni-3Mn alloy. The elongation decreased dramatically with increasing $\mathrm{Mn}$ content, from $18.0 \%$ for the $\mathrm{Al}-4 \mathrm{Ni}$ alloy to $8.6 \%$ and $5.2 \%$ for the $\mathrm{Al}-4 \mathrm{Ni}-2 \mathrm{Mn}$ and $\mathrm{Al}-4 \mathrm{Ni}-3 \mathrm{Mn}$ alloys, respectively. For the Al-4Ni-4Mn alloy, the elongation was only $2.3 \%$, indicating brittle fracture. This corroborates the decreased ultimate tensile strength of the $\mathrm{Al}-4 \mathrm{Ni}-4 \mathrm{Mn}$ alloy.

The tensile properties at $250^{\circ} \mathrm{C}$ are shown in Fig. 3c, revealing that $\mathrm{Mn}$ addition improved both the yield strength and ultimate tensile strength at this temperature. The yield strength was $35 \mathrm{MPa}$ for the Al-4Ni alloy but $82 \mathrm{MPa}$ for the Al-4Ni-2Mn alloy, corresponding to an increase of $134 \%$. When the Mn level was increased to $3.01 \%$ and $3.77 \%$, the yield strength increased monotonically to $96 \mathrm{MPa}$ and $101 \mathrm{MPa}$, respectively. Meanwhile, the ultimate tensile strength increased from $51 \mathrm{MPa}$ for the $\mathrm{Al}$ $4 \mathrm{Ni}$ alloy to $120 \mathrm{MPa}$ for the $\mathrm{Al}-4 \mathrm{Ni}-2 \mathrm{Mn}$ alloy, then to $143 \mathrm{MPa}$ when the $\mathrm{Mn}$ level was increased further to $3.77 \%$. The elongation at $250^{\circ} \mathrm{C}$ was much higher than that at ambient temperature, but addition of $\mathrm{Mn}$ decreased the elongation dramatically at $250^{\circ} \mathrm{C}$. The elongation was $49.0 \%$ for the Al$4 \mathrm{Ni}$ alloy and $17.9 \%$ for the $\mathrm{Al}-4 \mathrm{Ni}-2 \mathrm{Mn}$ alloy, but decreased further to $11.9 \%$ and $3.7 \%$ for the Al-4Ni$3 \mathrm{Mn}$ alloy and $\mathrm{Al}-4 \mathrm{Ni}-4 \mathrm{Mn}$ alloy, respectively.

Moreover, the alloys with Mn addition presented less strength loss when the temperature was increased to $250^{\circ} \mathrm{C}$. Table II presents the strength loss of the experimental alloys. Clearly, the alloys with Mn addition presented less strength loss. The $\mathrm{Al}-4 \mathrm{Ni}$ alloy showed a reduction of $27 \%$ in the yield strength between $25^{\circ} \mathrm{C}$ and $250^{\circ} \mathrm{C}$. However, the Al$4 \mathrm{Ni}-2 \mathrm{Mn}$ alloy showed only $10 \%$ yield strength loss. Meanwhile, the Al-4Ni-3Mn alloy and Al-4Ni-4Mn alloy presented $12 \%$ and $14 \%$ yield strength loss, respectively. Similarly, the ultimate tensile strength of the $\mathrm{Al}-4 \mathrm{Ni}$ alloy showed a $60 \%$ reduction while the Al-4Ni-2Mn alloy only showed $41 \%$. The $\mathrm{Al}-4 \mathrm{Ni}-3 \mathrm{Mn}$ alloy and $\mathrm{Al}-4 \mathrm{Ni}-4 \mathrm{Mn}$ alloy presented $37 \%$ and $34 \%$ ultimate tensile strength loss respectively between $25^{\circ} \mathrm{C}$ and $250^{\circ} \mathrm{C}$, being less than for the Al-4Ni alloy. It can thus be concluded that $\mathrm{Mn}$ addition can effectively improve the softening resistance of $\mathrm{Al}-4 \mathrm{Ni}$ alloys at evaluated temperatures.

\section{Isothermal Holding at $250^{\circ} \mathrm{C}$}

To study the thermal stability of Al-Ni-Mn alloys, the $\mathrm{Al}-4 \mathrm{Ni}-2 \mathrm{Mn}$ alloy was held at $250^{\circ} \mathrm{C}$ for different times from $100 \mathrm{~h}$ to $2000 \mathrm{~h}$. The microstructures are displayed in Fig. 4. The eutectic $\mathrm{Al}_{9}(\mathrm{Ni}, \mathrm{Mn})_{2}$ phase remained rod-like shape after $2000 \mathrm{~h}$ at $250^{\circ} \mathrm{C}$, and no coarsening was observed. Moreover, no precipitates were observed in the primary $\alpha-\mathrm{Al}$ after $2000 \mathrm{~h}$ at $250^{\circ} \mathrm{C}$. 
Table I. Volume fraction of different phases in experimental Al-Ni-Mn alloys

\begin{tabular}{|c|c|c|c|}
\hline \multirow[b]{2}{*}{ Alloy } & \multicolumn{3}{|c|}{ Volume fraction (vol.\%) } \\
\hline & Primary $\alpha$-Al (\%) & Eutectic phases (\%) & Intermetallic phases (\%) \\
\hline $\mathrm{Al}-4 \mathrm{Ni}$ & 56 & 44 & - \\
\hline $\mathrm{Al}-4 \mathrm{Ni}-2 \mathrm{Mn}$ & 49 & 51 & - \\
\hline $\mathrm{Al}-4 \mathrm{Ni}-3 \mathrm{Mn}$ & 41 & 58 & 1 \\
\hline $\mathrm{Al}-4 \mathrm{Ni}-4 \mathrm{Mn}$ & 35 & 60 & 5 \\
\hline
\end{tabular}

Table II. Strength loss of Al-4Ni and Al-4Ni-xMn alloys at $250^{\circ} \mathrm{C}$

\begin{tabular}{|c|c|c|}
\hline \multirow[b]{2}{*}{ Alloy } & \multicolumn{2}{|c|}{ Strength loss } \\
\hline & Yield strength $(\%)$ & Ultimate tensile strength $(\%)$ \\
\hline $\mathrm{Al}-4 \mathrm{Ni}$ & 27 & 60 \\
\hline $\mathrm{Al}-4 \mathrm{Ni}-2 \mathrm{Mn}$ & 10 & 41 \\
\hline $\mathrm{Al}-4 \mathrm{Ni}-3 \mathrm{Mn}$ & 12 & 37 \\
\hline $\mathrm{Al}-4 \mathrm{Ni}-4 \mathrm{Mn}$ & 14 & 34 \\
\hline
\end{tabular}
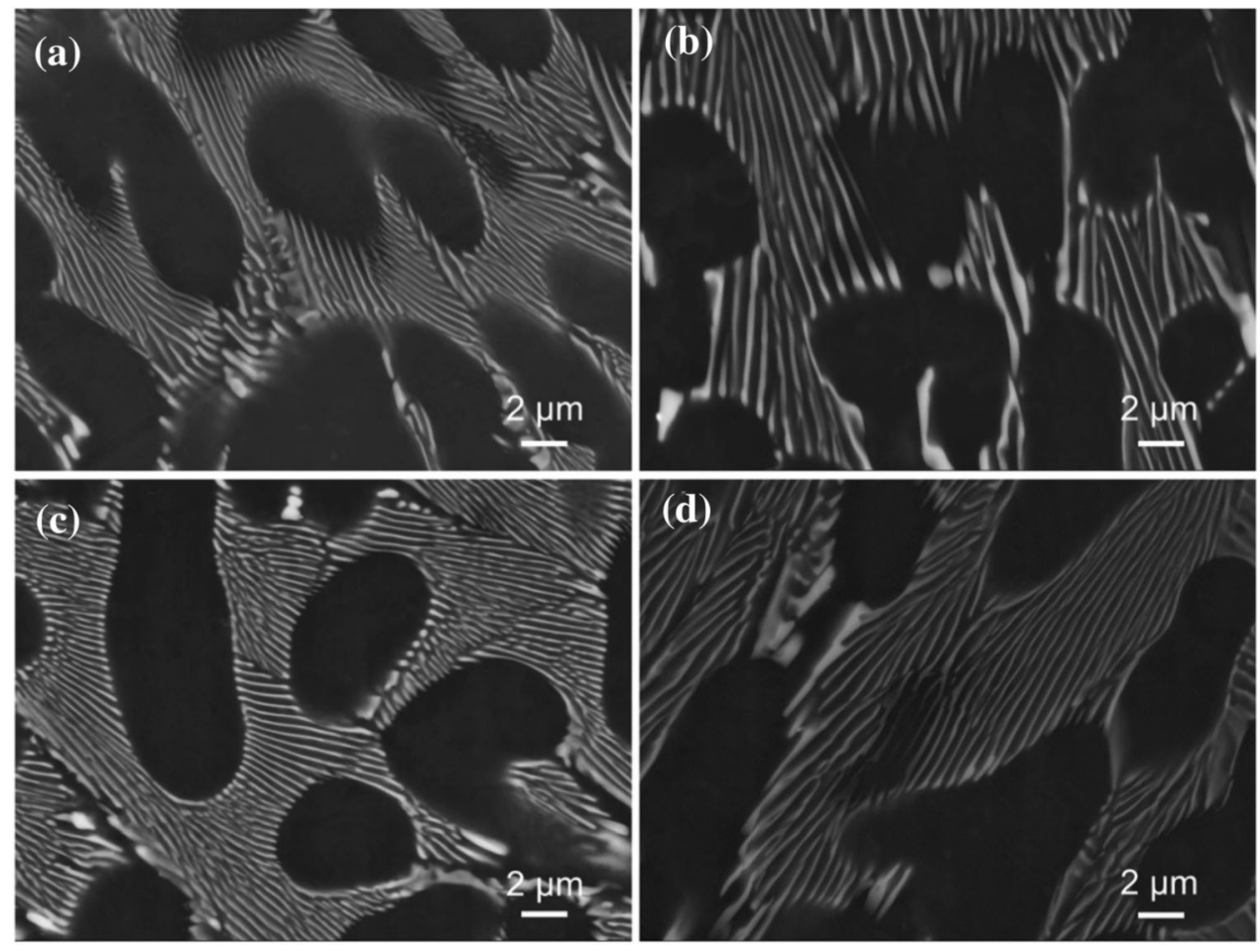

Fig. 4. Backscattered SEM micrographs showing microstructure of Al-4Ni-2Mn alloy after isothermal holding at $250^{\circ} \mathrm{C}$ for (a) $100 \mathrm{~h}$, (b) $540 \mathrm{~h}$, (c) $1000 \mathrm{~h}$, and (d) $2000 \mathrm{~h}$.

Figure 5 presents the Vickers hardness of the Al$4 \mathrm{Ni}-2 \mathrm{Mn}$ alloy after isothermal holding at $250^{\circ} \mathrm{C}$ for various times. The hardness showed no obvious change, and the fluctuation was within a very narrow range. The hardness increased from 64.5 $\mathrm{HV}_{10}$ for the as-cast sample to $69.0 \mathrm{HV}_{10}$ after holding at $250^{\circ} \mathrm{C}$ for $540 \mathrm{~h}$. The hardness after holding for $2000 \mathrm{~h}$ was still $68.1 \mathrm{HV}_{10}$.

The eutectic $\mathrm{Al}_{9}(\mathrm{Ni}, \mathrm{Mn})_{2}$ showed good stability at $250^{\circ} \mathrm{C}$. However, the $\mathrm{Al}_{3} \mathrm{Ni}$ phase is also thermally stable at $250^{\circ} \mathrm{C}$. Hence, this is not sufficient to explain why the alloys with Mn addition experienced less strength loss. As mentioned above, the 


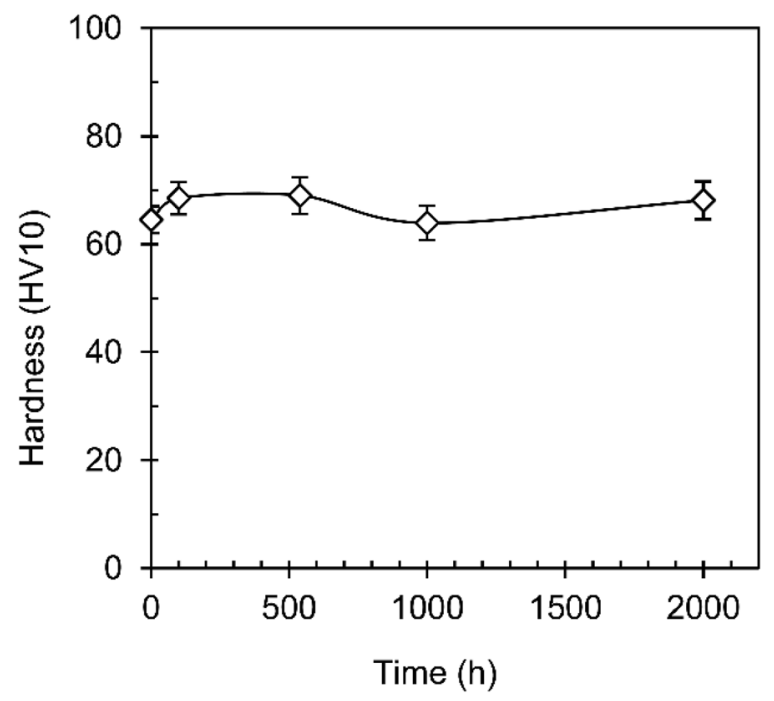

Fig. 5. Hardness of Al-4Ni-2Mn alloy after isothermal holding at $250^{\circ} \mathrm{C}$ for different times.

main difference between the $\mathrm{Al}-4 \mathrm{Ni}$ and $\mathrm{Al}-4 \mathrm{Ni}-2 \mathrm{Mn}$ alloys is the eutectic structure, which was $\mathrm{Al}_{3} \mathrm{Ni} / \alpha-$ $\mathrm{Al}$ and $\mathrm{Al}_{9}(\mathrm{Ni}, \mathrm{Mn})_{2} / \alpha-\mathrm{Al}$, respectively. Hence, the difference in their strength loss may be related to different softening behavior between $\mathrm{Al}_{9}(\mathrm{Ni}, \mathrm{Mn})_{2}$ and $\mathrm{Al}_{3} \mathrm{Ni}$ phases. The microhardness of $\alpha-\mathrm{Al}, \mathrm{Al}_{3} \mathrm{Ni}$, and $\mathrm{Al}_{9} \mathrm{FeNi}$ phases is reported in Ref. 30 No data for $\mathrm{Al}_{9}(\mathrm{Ni}, \mathrm{Mn})_{2}$ phase were reported, but $\mathrm{Al}_{9} \mathrm{FeNi}$ phase was found. The $\mathrm{Al}_{9} \mathrm{FeNi}^{26}$ phase is also known as $\mathrm{Al}_{9}(\mathrm{Fe}, \mathrm{Ni})_{2}$; It shows the same monoclinic $\mathrm{Al}_{9} \mathrm{Co}_{2}$ structure as the $\mathrm{Al}_{9}(\mathrm{Ni}, \mathrm{Mn})_{2}$ phase. Also, the composition of $\mathrm{Al}_{9} \mathrm{FeNi}$ phase was $\mathrm{Al}-13.4$ at. $\% \mathrm{Ni}-$ 4.2 at. $\% \mathrm{Fe}$, close to that of the $\mathrm{Al}_{9}(\mathrm{Ni}, \mathrm{Mn})_{2}$ phase (Al-13.5 at.\%Ni -3.7 at.\%Mn). Moreover, Fe and Mn are next to each other in the Periodic Table. These two elements have very similar atomic radii $\left(r_{\mathrm{Mn}}=\right.$ $1.40 \AA, r_{\mathrm{Fe}}=1.26 \AA$ ) and can replace each other in many intermetallic phases. In addition, the $\mathrm{Al}_{9} \mathrm{FeNi}$ phase and $\mathrm{Al}_{9}(\mathrm{Ni}, \mathrm{Mn})_{2}$ contain a relatively low level of $\mathrm{Fe}$ and $\mathrm{Mn}$, respectively. It is thus expected that $\mathrm{Mn}$ atoms will replace $\mathrm{Fe}$ atoms. The $\mathrm{Al}_{9} \mathrm{FeNi}$ and $\mathrm{Al}_{9}(\mathrm{Ni}, \mathrm{Mn})_{2}$ phase should present similar hardness and softening behavior at elevated temperatures.

The microhardness at different temperatures is shown in Fig. 6a. The microhardness of $\mathrm{Al}_{9} \mathrm{FeNi}$ phase was $7.71 \mathrm{GPa}$ at ambient temperature, while that of $\mathrm{Al}_{3} \mathrm{Ni}$ was only $5.95 \mathrm{GPa}$. When the temperature was increased to $350^{\circ} \mathrm{C}$, the hardness of the $\mathrm{Al}_{9} \mathrm{FeNi}$ phase was $5.83 \mathrm{GPa}$ while that of $\mathrm{Al}_{3} \mathrm{Ni}$ was only $3.54 \mathrm{GPa}$. The $\mathrm{Al}_{9} \mathrm{FeNi}$ phase showed higher hardness than the $\mathrm{Al}_{3} \mathrm{Ni}$ phase at both ambient and elevated temperature. In addition, the hardness of the $\alpha-\mathrm{Al}$ phase decreased dramatically from 1.45 $\mathrm{GPa}$ to $0.143 \mathrm{GPa}$ when the temperature was increased to $350^{\circ} \mathrm{C}$, indicating that the $\alpha$-Al phase softens quickly at elevated temperatures. Figure $6 \mathrm{~b}$ presents the fraction of the hardness remaining at elevated temperatures for the different phases. Clearly, $\mathrm{Al}_{9} \mathrm{FeNi}$ phase retained higher hardness
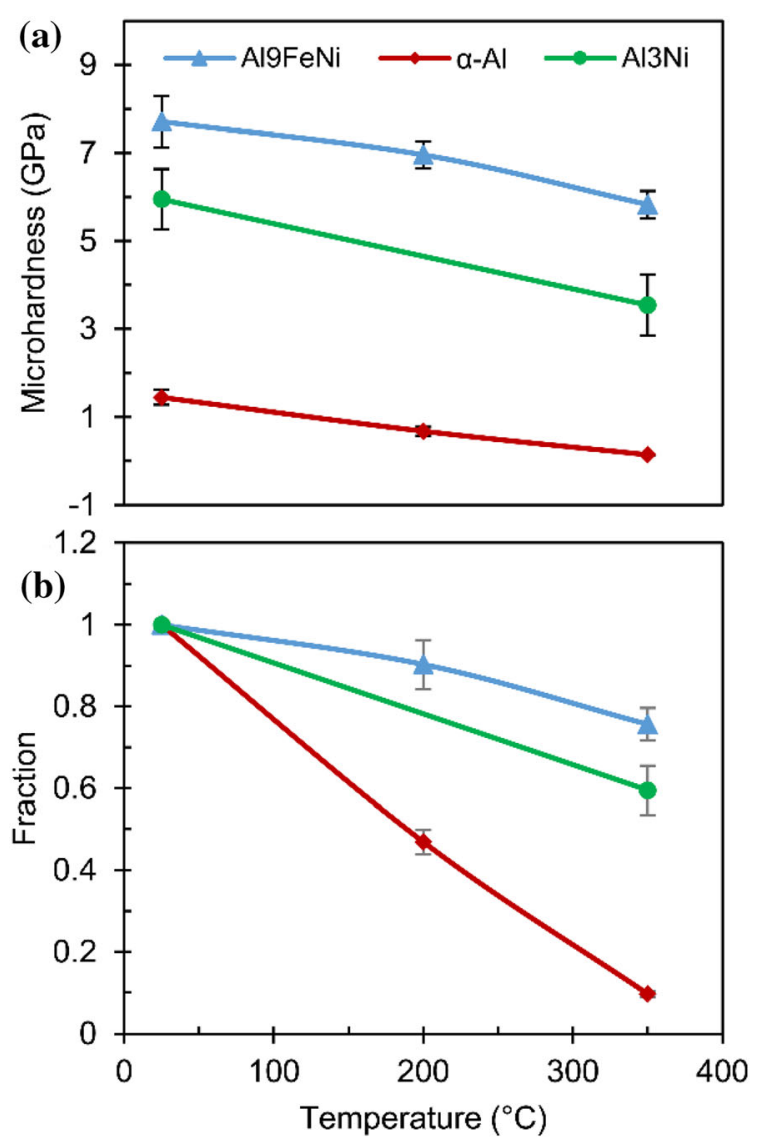

Fig. 6. (a) Microhardness of $\alpha-\mathrm{Al}, \mathrm{Al}_{3} \mathrm{Ni}$, and $\mathrm{Al}_{9} \mathrm{FeNi}$ phases and (b) fraction of microhardness remaining at different temperatures.

than the $\mathrm{Al}_{3} \mathrm{Ni}$ phase. When the temperature was increased to $350^{\circ} \mathrm{C}$, the $\mathrm{Al}_{9} \mathrm{FeNi}$ phase maintained $75.6 \%$ of its hardness while the $\mathrm{Al}_{3} \mathrm{Ni}$ phase maintained only $59.5 \%$. Hence, the $\mathrm{Al}_{9} \mathrm{FeNi}$ phase showed better softening resistance than the $\mathrm{Al}_{3} \mathrm{Ni}$ phase at elevated temperatures. Therefore, it is expected that the $\mathrm{Al}_{9}(\mathrm{Ni}, \mathrm{Mn})_{2}$ phase will also present higher softening resistance than the $\mathrm{Al}_{3} \mathrm{Ni}$ phase. Similarly, the eutectic $\mathrm{Al}_{9}(\mathrm{Ni}, \mathrm{Mn})_{2} / \alpha-\mathrm{Al}$ structure displayed better softening resistance than the $\mathrm{Al}_{3} \mathrm{Ni} / \alpha-\mathrm{Al}$ structure. Therefore, the transformation of the eutectic from $\mathrm{Al}_{3} \mathrm{Ni}$ to $\mathrm{Al}_{9}(\mathrm{Ni}, \mathrm{Mn})_{2}$ can improve the softening resistance with less strength loss at $250^{\circ} \mathrm{C}$.

\section{CONCLUSION}

1. Mn addition transformed the eutectic intermetallic phase from $\mathrm{Al}_{3} \mathrm{Ni}$ to $\mathrm{Al}_{9}(\mathrm{Ni}, \mathrm{Mn})_{2}$ phase. The $\mathrm{Al}_{9}(\mathrm{Ni}, \mathrm{Mn})_{2}$ phase showed rod-like shape. With increasing Mn content, k-phase, O-phase, and $\mathrm{Al}_{6} \mathrm{Mn}$ phase formed as primary phases in Al-Ni-Mn alloys.

2. Mn addition significantly improved the mechanical performance of cast $\mathrm{Al}-4 \mathrm{Ni}$ alloy at ambient temperature and at $250^{\circ} \mathrm{C}$. This improvement is due to the solid solution of $\mathrm{Mn}$ in $\alpha-\mathrm{Al}$ and the 
increase of eutectic phases and primary intermetallic phases with increasing Mn content.

3. Mn addition improved the softening resistance. Alloys with Mn addition presented less strength loss than the $\mathrm{Al}-4 \mathrm{Ni}$ alloy when the temperature was increased to $250^{\circ} \mathrm{C}$. The eutectic $\mathrm{Al}_{9}(-$ $\mathrm{Ni}, \mathrm{Mn})_{2}$ phase displayed higher softening resistance than the $\mathrm{Al}_{3} \mathrm{Ni}$ phase.

4. The eutectic intermetallic $\mathrm{Al}_{9}(\mathrm{Ni}, \mathrm{Mn})_{2}$ phase showed good thermal stability at $250^{\circ} \mathrm{C}$. No coarsening was observed after $2000 \mathrm{~h}$, and no precipitates were observed in $\alpha$-Al. The hardness showed no decrease after isothermal holding at $250^{\circ} \mathrm{C}$ for up to $2000 \mathrm{~h}$.

\section{ACKNOWLEDGEMENT}

Financial support from Jaguar Land Rover for Jiao Fang's PhD study is gratefully acknowledged.

\section{CONFLICT OF INTEREST}

On behalf of all authors, the corresponding author states that there is no conflict of interest.

\section{OPEN ACCESS}

This article is licensed under a Creative Commons Attribution 4.0 International License, which permits use, sharing, adaptation, distribution and reproduction in any medium or format, as long as you give appropriate credit to the original author(s) and the source, provide a link to the Creative Commons licence, and indicate if changes were made. The images or other third party material in this article are included in the article's Creative Commons licence, unless indicated otherwise in a credit line to the material. If material is not included in the article's Creative Commons licence and your intended use is not permitted by statutory regulation or exceeds the permitted use, you will need to obtain permission directly from the copyright holder. To view a copy of this licence, visit http://creativecommons.org/licenses/by/4.0/.

\section{REFERENCES}

1. H. Ye, J. Mater. Eng. Perform. 12, 288. (2003).
2. K.E. Knipling, D.C. Dunand, and D.N. Seidman, Z. Met. 97, 246. (2006).

3. O. Elsebaie, A.M.A. Mohamed, A.M. Samuel, F.H. Samuel, and A.M.A. Ahmari, Mater. Des. 32, 3205. (2011).

4. W. Kasprzak, B.S. Amirkhiz, and M. Niewczas, J. Alloys Compd. 595, 67. (2014).

5. T. Gao, X. Zhu, Q. Sun, and X. Liu, J. Alloys Compd. 567, 82. (2013).

6. X.G. Chen, and M. Fortier, J. Mater. Process. Technol. 210, 1780. (2010)

7. Y. Li, Y. Yang, Y. Wu, L. Wang, and X. Liu, Mater. Sci. Eng. A 527, 7132. (2010).

8. J. Røyset, and N. Ryum, Int. Mater. Rev. 50, 19. (2005).

9. C.B. Fuller, D.N. Seidman, and D.C. Dunand, Acta Mater. 51, 4803. (2003).

10. M. Rahimian, S. Amirkhanlou, P. Blake, and S. Ji, Mater. Sci. Eng. A 721, 328. (2018).

11. Y. Harada, and D.C. Dunand, Intermetallics 17, 17. (2009).

12. H.A. Elhadari, H.A. Patel, D.L. Chen, and W. Kasprzak, Mater. Sci. Eng. A 528, 8128. (2011).

13. G. Liu, P. Blake, and S. Ji, J. Alloys Compd. 809, 151795. (2019).

14. R.E. Franck, and J.A. Hawk, Scr. Metall. 23, 113. (1989).

15. P.Y. Li, H.J. Yu, S.C. Chai, and Y.R. Li, Scr. Mater. 49, 819. (2003).

16. W.J. Golumbfskie, M.F. Amateau, T.J. Eden, J.G. Wang, and Z.K. Liu, Acta Mater. 51, 5199. (2003).

17. P.Y. Li, S.L. Dai, C.Y. Li, and B.C. Liu, Acta Metall. Sin. 12 452. (1999).

18. V.S. Zolotorevsky, N.A. Belov, and M.V. Glazoff, Casting Aluminum Alloys (Elsevier, Amsterdam, 2007), pp 230-232.

19. V. Raghavan, J. Phase Equilibria Diffus. 27, 493. (2006).

20. Y. Fan, K. Huang, and M.M. Makhlouf, Metall. Mater. Trans. A Phys. Metall. Mater. Sci. 46, 5830. (2015).

21. H. Okamoto, J. Phase Equilibria Diffus. 25, 394. (2004).

22. J.L. Murray, and A.J. McAlister, Bull. Alloy Phase Diagr. 5, 74. (1984).

23. A. Jansson, Metall. Trans. A 23, 2953. (1992).

24. S. Balanetskyy, G. Meisterernst, B. Grushko, and M. Feuerbacher, J. Alloys Compd. 509, 3795. (2011).

25. W. Yu, Q. Hao, L. Fan, and J. Li, J. Alloys Compd. 688, 798. (2016).

26. I. Chumak, K.W. Richter, and H. Ipser, Intermetallics 15, 1416. (2007).

27. A. Sato, A. Yamamoto, X.Z. Li, K. Hiraga, T. Haibach, and W. Steurer, Acta Crystallogr. Sect. C Cryst. Struct. Commun. 53, 1531. (1997).

28. G.V. Raynor, J. Inst. Met. 70, 507. (1944).

29. K. Robinson, Acta Crystallogr. 7, 494. (1954).

30. C.L. Chen, G.D. West, and R.C. Thomson, Mater. Sci. Forum 519-521, 359. (2006).

Publisher's Note Springer Nature remains neutral with regard to jurisdictional claims in published maps and institutional affiliations. 